\title{
In vitro degradation and cytocompatibility evaluation of novel soy and sodium caseinate- based membrane biomaterials
}

\author{
G. A. SILVA ${ }^{1,2 *}$, C. M. VAZ ${ }^{1}$, O. P. COUTINHO ${ }^{2,3}$, A. M. CUNHA ${ }^{1}$, R. L. REIS ${ }^{1,2}$ \\ ${ }^{1}$ Department of Polymer Engineering, University of Minho, Campus de Azurém, 4800-058 \\ Guimarães, Portugal \\ E-mail:gsilva@dep.uminho.pt \\ ${ }^{2} 3 B^{\prime}$ 's Research Group, University of Minho, Campus de Gualtar, 4710-057 Braga, Portugal \\ ${ }^{3}$ Department of Biology, University of Minho, Campus de Gualtar, 4710-057 Braga, Portugal
}

\begin{abstract}
Soy- and casein-based membranes are newly proposed materials disclosing a combination of properties that might allow for their use in a range of biomedical applications. Two of the most promising applications are drug delivery carrier systems and wound dressing membranes. As for all newly proposed biomaterials, a cytotoxic scanning must be performed as a preliminary step in the process of the determination of the compatibility with biological systems (biocompatibility). In this study, the cytotoxicity of both soy- and caseinbased protein biomaterials has been evaluated and correlated with the materials degradation behavior. It was possible to show, through morphological and biochemical tests that these natural origin materials do not exert any cytotoxic effect over cells, and in some cases can in fact enhance cell proliferation. The different treatments to which the membranes were subjected during their processing (that include crosslinking with glyoxal and tannic acid, and physical modification by thermal treatment) seemed to have a clear effect both on the materials mechanical properties and on their in vitro biological behavior.
\end{abstract}

(C) 2003 Kluwer Academic Publishers

\section{Introduction}

Natural origin biomaterials are currently under study for several biomedical applications, due to their advantageous properties, namely their degradability, availability and renewable origin. Furthermore, they are easily to be processed (both by solvent- and melt-based routes), which results in low cost products. Naturally derived materials offer many mechanical, chemical and biological advantages over synthetic materials, making them suitable for tissue engineering applications [1].

For instance, starch-based materials have already proven to be suitable for several biomedical applications, that range from drug delivery systems, to hydrogels, bone cements and tissue engineering scaffolds in several studies, both in vitro and in vivo [2-7]. Their biocompatibility has already been proved, as documented elsewhere $[4,8,9]$. In this work, soy protein, the major component of the soybean [10] and casein, the major protein present in milk and other biological products, have been studied. Both materials are known proteins that have previously shown [10-12] to have good mechanical, dynamical and thermal properties, which make them suitable for several biomedical applications. Proposed applications include drug delivery carrier systems and wound dressing membranes.
The amino acids that constitute soy protein are aspartic and glutamic acid, together with non-polar amino acids such as glycine, alanine, valine and leucine, and basic aminoacids: lysine, arginine and also cysteine, which is present at $<1 \%$ [10]. Milk has a protein content of about $33 \mathrm{~g} / \mathrm{l}$ and the two major protein fractions are caseins (about 80\%) and whey proteins (about 20\%) $[13,14]$. Caseins are predominantly phosphoproteins that precipitate at $\mathrm{pH} 4.6\left(20^{\circ} \mathrm{C}\right)$ and, which are characterized by an open, random coil structure $[13,14]$. By treating acid-precipitated caseins with alkali solutions caseinates are produced [13,14]. Caseins and caseinates form transparent and flexible films from aqueous solutions without treatment due to their random coil nature and numerous hydrogen bonds [13,14]. It is not surprising that caseins and soy have shown to be useful proteins for the microencapsulation of insecticides [15], food ingredients [16] and pharmaceutics [12,17].

All materials that are aimed to be used in biomedical applications must be evaluated for their biocompatibility, both in vitro and in vivo. The ISO/EN 10993-5 guidelines [18] rule the types of tests to be performed for the evaluation of the proposed biomaterials. In the present work, the cytocompatibility of soy- and casein-based membranes was determined in accordance with these

*Author to whom all correspondence should be addressed. 
guidelines. The basic idea was not to perform any regulatory trial but use these well-known tests to perform a preliminary evaluation of the cytotoxicity of novel biomaterials that have never been tested before in contact with cells. The interpretation of results is purely scientific and does not want in any way to prove that the materials will pass a regulatory trial, although that might be expectable. In fact, if materials not produced under GMP conditions and not produced in high purity or in clean room environment are non-cytotoxic, one might extrapolate that the same materials would be non-cytotoxic if produced under GMP conditions.

The first evaluation should be performed in cell lines, in direct and indirect contact tests. The indirect contact tests are performed by placing in contact with the cells extracts from the materials and evaluate the cellular response to the materials' leachables, while in direct contact tests the cells are cultured in contact with the materials themselves and the morphological features are periodically evaluated. In the direct contact test, the proposed biomaterials should be tested with cell populations typical of the implant site [19], in order to obtain a more accurate response similar to the one in vivo.

The degradation profile of the materials is important when evaluating indirectly the effects of the proposed biomaterials, since it can help explaining the effects observed over cells by the materials' leachables.

In this work, both standard extraction and direct contact cell adhesion and proliferation tests were carried out for both types of protein-based membranes, as well as degradation and water-uptake capabilities to evaluate in a first-base the potential of these newly proposed materials to be used for biomedical applications.

\section{Materials and methods}

In this study, soy (SI) and sodium caseinate (NaCas)based membranes crosslinked with two different agents glyoxal and tannic acid - and subjected to physical treatment, were used.

\subsection{Membranes preparation}

Film-forming solutions were prepared at $40{ }^{\circ} \mathrm{C}$ by slowly suspending the protein powders $(10 \%$, w/w), under constant stirring, in distilled water with glycerol $(20 \%$, $\mathrm{w} / \mathrm{w}$ relative to protein content). After adjusting the $\mathrm{pH}$ to $8.0 \pm 0.1$ with $1 \mathrm{M} \mathrm{NaOH}$, glyoxal (GLX) or tannic acid
(TA) solutions were added to the referred solutions at a level of $0 \%$ and $0.9 \%(\mathrm{w} / \mathrm{w}$ relative to the protein amount $\quad$ (SI(NaCas), $\quad \mathrm{SI}(\mathrm{NaCas})+\mathrm{GLX}$ and $\mathrm{SI}(\mathrm{NaCas})+\mathrm{TA})$. The suspensions were cast into Petri dishes followed by air-drying for about $24 \mathrm{~h}$ at room temperature (RT) and relative humidity (RH). After drying, the obtained films $(100 \mu \mathrm{m}$ thick) were peeled off the dishes and cut into appropriate shapes for property evaluation. All the specimens were stored in desiccator (58\% RH and RT) until use.

Dried films were mounted on glass plates by applying tape round the film edges and heated at $80^{\circ} \mathrm{C}$ in a forced convection oven for $24 \mathrm{~h}$ ( $\mathrm{SI}(\mathrm{NaCas})+\mathrm{PM}$, $\mathrm{SI}(\mathrm{NaCas})+\mathrm{GLX}+\mathrm{PM}$ and $\mathrm{SI}(\mathrm{NaCas})+\mathrm{TA}+\mathrm{PM})$. The tape held films flat and prevented curling and rippling during heating. Following these heat treatments, the films were again conditioned in the desiccator $(58 \%$ $\mathrm{RH}$ and RT) until property evaluation.

The different samples tested in this work were as follows in Table I.

After processing and modification, the membranes were cut with different dimensions in accordance with the experiments to be performed. For in vitro degradation tests, $7 \times 0.4 \mathrm{~cm}^{2}$ dumb-bell tensile test samples were used. For the permeability tests, circular samples with $\varnothing 8.5 \mathrm{~cm}$ were produced. Cytotoxicity assays were performed using $1 \times 3 \mathrm{~cm}^{2}$ portions, and for adhesion and proliferation studies portions with dimensions of $1 \times 1 \mathrm{~cm}^{2}$. The membranes were ethylene oxide sterilized prior to testing, and this sterilization process did not affect the samples (data not shown). Further information on the properties of similar membranes may be found in works of Vaz et al. [10-12]

\subsection{In vitro degradation tests}

Protein membranes were submitted to in vitro degradation tests. Pre-weighed dry specimens were immersed up to 15 days in an isotonic saline solution (ISS: $\mathrm{NaCl}, 9 \mathrm{~g} / \mathrm{l}$, $\mathrm{pH}=7.40 \pm 0.02)$ at $37^{\circ} \mathrm{C}$. After pre-fixed aging periods $(0,1,7$ and 15 days of immersion), the films were removed from the aging solution, washed with distilled water and dried in a vacuum oven $\left(40^{\circ} \mathrm{C} / 24 \mathrm{~h}\right)$. The percentage weight loss of the protein films were then calculated from the Equation 1.

$$
W L_{t}=\left[\left(W_{0}-W_{t}\right) / W_{0}\right] \times 100
$$

where $W L_{t}$ is the weight loss of the films after a certain

T A B L E I Samples of soy and casein-based membranes evaluated for their cytotoxic profile

\begin{tabular}{|c|c|}
\hline Samples & Abrev. \\
\hline Soy membranes & SI \\
\hline Soy membranes with physical modification & $\mathrm{SI}+\mathrm{PM}$ \\
\hline Soy membranes crosslinked with glyoxal & $\mathrm{SI}+\mathrm{GLX}$ \\
\hline Soy membranes crosslinked with glyoxal subjected to physical modification & $\mathrm{SI}+\mathrm{GLX}+\mathrm{PM}$ \\
\hline Soy membranes crosslinked with tannic acid & $\mathrm{SI}+\mathrm{TA}$ \\
\hline Soy membranes crosslinked with tannic acid subjected to physical modification & $\mathrm{SI}+\mathrm{TA}+\mathrm{PM}$ \\
\hline Sodium caseinate membranes & $\mathrm{NaCas}$ \\
\hline Sodium caseinate membranes subjected to physical modification & $\mathrm{NaCas}+\mathrm{PM}$ \\
\hline Sodium caseinate membranes crosslinked with glyoxal & $\mathrm{NaCas}+\mathrm{GLX}$ \\
\hline Sodium caseinate membranes crosslinked with tannic acid & $\mathrm{NaCas}+\mathrm{TA}$ \\
\hline Sodium caseinate membranes crosslinked with tannic acid subjected to physical modification & $\mathrm{NaCas}+\mathrm{TA}+\mathrm{PM}$ \\
\hline
\end{tabular}


time, $t$, of immersion. $W_{t}$ denotes the weight of the films at aging time $t$ and $W_{0}$ is the initial dry weight of the film. Each experiment was repeated three times and the average value was taken as the weight loss.

\subsection{Water-vapor transmission rate}

The moisture permeability of the membranes was determined by measuring the water-vapor transmission rate (WVTR) across the material as stipulated by a modified ASTM standard method E96-80 [20]. The test involved mounting of the test material in a specially designed cup containing dried silica. The material was positioned across the opening of the cup, which was placed in an incubator at $37^{\circ} \mathrm{C}$ and with a RH maintained at $58 \%$. Transmission of the water vapor through the test membranes was monitored by measurement of the increase in weight of the cup. Each experiment was repeated three times and the average value was taken as the WVTR.

\subsection{Cytotoxicity evaluation: indirect contact tests}

For cytotoxicity evaluation by indirect contact, three different tests were performed, namely Dulbecco's modified Eagle's medium (DMEM) extraction test, MTT test and total protein quantification test.

The cells used in this study were an immortalized cell line of fibroblasts from mouse origin purchased from Collection of Cell Culture, ECACC, UK (ref. 85011425), designated L929.

\subsubsection{DMEM extraction test}

This is an indirect contact test based on the morphological evaluation of parameters such as cell confluence, morphology, cell death and inhibition of growth [4], and is in accordance with ISO/EN 10993 guidelines [18]. The materials to be evaluated were extracted in culture medium for $24 \mathrm{~h}$ under constant stirring, filtered and then placed in contact with the cell monolayer. The parameters referred above were evaluated at 24,48 and $72 \mathrm{~h}$.

The different $1 \times 3 \mathrm{~cm}^{2}$ samples were placed in conic tubes with DMEM culture medium (Gibco BRL, UK) supplemented with $10 \%$ foetal bovine serum (Biochrome, Germany), 1\% antibiotic/antimycotic solution (Sigma, St Louis, USA) and $20 \mathrm{mM}$ HEPES (Sigma, St Louis, USA) at a ratio of $1.5 \mathrm{~cm}^{2} / \mathrm{ml}$. The conic tubes were placed in a waterbath with constant shaking (60 r.p.m.) at $37^{\circ} \mathrm{C}$ for $24 \mathrm{~h}$ for the materials to extract. Latex rubber is also extracted as positive control, i.e. as the maximum cytotoxic effect. Another extraction control was also used, which consists of complete DMEM culture medium. This control was performed to assure that the extraction conditions do not alter the properties of the culture medium. After $24 \mathrm{~h}$, the extracts were filtered through a $0.45 \mu \mathrm{m}$ pore size filter (Sarstedt, Germany). L929 cells grown on $75 \mathrm{~cm}^{2}$ flasks were resuspended using a $0.25 \%$ trypsin/EDTA solution (Sigma, St Louis, USA), and a cell suspension was prepared with the appropriate concentration so that each well of the 24 -well plate was seeded with $1 \times 10^{5}$ cells, in order to obtain a confluence of $80 \%$ by the time that the extracts are placed in contact with the cells. For this, the cell culture medium is removed by aspiration and $1 \mathrm{ml}$ of the extract medium is added to each well. The 24-well plate is then placed at $37^{\circ} \mathrm{C}$, in humidified atmosphere with $5 \% \mathrm{CO}_{2}$.

After 24, 48 and $72 \mathrm{~h}$, confluence of the cell monolayer, morphology of cells and cell death were evaluated microscopically in an inverted light microscope (Leica, Germany). At $72 \mathrm{~h}$, detaching cells using a $0.25 \%$ trypsin/EDTA solution and counting on a Neubauer chamber performed a cell count. The cytotoxic response was evaluated by a scoring system that uses an Excel sheet specially designed for this evaluation. Details on this methodology can be found elsewhere [4]. For each sample triplicates were made, and three different experiments with reproducible results were performed.

\subsubsection{MTT test}

The MTT test is a biochemical test widely used to assess cytotoxicity by measuring cell viability and proliferation in a qualitative way [21-23].

The materials were extracted as described above for the DMEM extraction test but in DMEM culture medium without phenol red, because this compound has shown to interfere with the MTT test. L929 cells were seeded in a 96-well plate in order to obtain $90-100 \%$ confluence at the time of placing the extracts in contact with the cells. The extract medium is added to cells and incubated at $37^{\circ} \mathrm{C}$, in a humidified atmosphere with $5 \% \mathrm{CO}_{2}$ for $72 \mathrm{~h}$, after which the MTT test is performed.

A MTT (Sigma, St Louis, USA) solution of $1 \mathrm{mg} / \mathrm{ml}$ in DMEM culture medium without phenol red (supplemented as described above) added to each well. The plate is then incubated at $37^{\circ} \mathrm{C}$, in a humidified atmosphere for $4 \mathrm{~h}$ after which an isopropanol/ $\mathrm{HCl}$ solution is added to each well and further incubated for $15 \mathrm{~min}$ in order to enhance the dissolution of the formazan crystals. The optical densities at $570 \mathrm{~nm}$ and $650 \mathrm{~nm}$ (background) were read on a multiwell plate reader (Molecular Dynamics, Amersham, USA) against a blank of MTT solution and isopropanol. All the materials were tested in five replicates for each extract for at least three separate experiments with reproducible results. The results are expressed as mean \pm standard errors.

\subsubsection{Total protein quantification}

The method that was used to quantify the total protein uses the Micro BCA Protein Assay Reagent kit (Pierce, USA), in which bicinchoninic acid (BCA) is the detection reagent for a $\mathrm{Cu}$ complex, which is formed when $\mathrm{Cu}^{2+}$ is reduced by proteins in an alkaline environment [24]. The purple color product is due to the chelation of two molecules of BCA with one $\mathrm{Cu}$ ion. This complex is water-soluble and absorbs at $562 \mathrm{~nm}$, and its optical density is linearly correlated with protein concentration [24].

The procedure followed is as described for the MTT test. After the $72 \mathrm{~h}$ incubation, the extracts are removed 
from contact with cells and $0.01 \mathrm{M}$ phosphate buffered saline (PBS) are added to each well of the 96-well plate. The BCA reagent was added to each well, the plate incubated for $2 \mathrm{~h}$ after which the optical densities were measured at $562 \mathrm{~nm}$ against a blank of PBS $0.01 \mathrm{M}$ and $\mathrm{BCA}$ reagent. Total protein (in $\mu \mathrm{g}$ ) was determined using a BSA standard curve with concentrations ranging from 0 to $400 \mu \mathrm{g} / \mathrm{ml}$.

Since this test scores for the total protein present within the well, there was the possibility that the extracts from the protein-based materials might contain some small peptides that would be quantified, since this quantification method acts by detecting simple peptide bonds. In this way, an appropriate control was performed, being that for each extract added to cells was also placed alone in different well in the same number of replicates. In this way, the eventually leached peptides would quantify and subtracted to the values of total protein presented by the cells.

All the materials were tested in five replicates for each extract for at least three separate experiments, with reproducible results. The results are expressed as mean \pm standard errors.

\subsection{Cytotoxicity evaluation: direct contact tests}

\subsubsection{SEM evaluation}

For the scanning electron microscope (SEM) studies, $1 \times 1 \mathrm{~cm}^{2}$ membranes were placed in 24-well plates treated to prevent cell adhesion (Costar Ultra Low Attachment Clusters), so that no competition between the plate surface and the membranes surface occurred. The first step was the rehydration of the surface of the wells in the plate according to the supplier instructions. Then, a cell suspension was prepared and cells were plate seeded at a density of $5 \times 10^{4}$ cells/well by gently depositing the cell suspension over the membrane. The total volume of $1 \mathrm{ml}$ is then completed with culture medium.

After 7 days, the membranes in contact with the L929 cells were fixated with a solution of $2.5 \%$ glutaraldehyde and dehydrated with growing ethanol concentrations (50\%, 70\%, 90\% and 100\%). and then air-dried. Membranes without contact with cells (day 0) were treated equally to membranes in contact with cells, in order to assess the eventual modifications in the surface of the membranes caused by the fixation and dehydration process.

The samples were then gold coated by ion sputtering by a Sputter Jeol JFC 1100 equipment and observed using a SEM (Leica, Cambridge S360).

\section{Results and discussion}

\subsection{In vitro degradation studies}

Protein-based materials can be stabilized by chemical crosslinking (Figs. 1 and 2). Crosslinking using glyoxal involves the reaction between the aldehyde groups of the glyoxal and the free $\varepsilon$-amine groups of lysine or hydroxylysine residues of the polypeptide chains [25]. The results obtained revealed that the treatment with glyoxal drastically decreased the weight loss rate for $\mathrm{NaCas}$ (Fig. 2). In contrast, treatment of SI with glyoxal only decreased its weight loss rate during the first days of immersion (Fig. 1).

The aging of $\mathrm{NaCas}+\mathrm{GLX}$ in an isotonic saline solution resulted in a weight loss of $\sim 20 \%$ after $24 \mathrm{~h}$ of immersion time (rate of weight loss $0.83 \%$ per hour) (Fig. 2). This corresponds to an improvement of $80 \%$, as $\mathrm{NaCas}$ showed a weight loss of $100 \%$ in $24 \mathrm{~h}$ of immersion (which is $4 \%$ per hour). During this initial period, the weight loss of the crosslinked samples is only due to the loss of the $20 \%(\mathrm{w} / \mathrm{w})$ glycerol used in the preparation of the membranes. After $168 \mathrm{~h}$ of immersion, the partially degraded samples lost only $\sim 10 \%$ weight for SI and $\sim 30 \%$ weight for NaCas. Two weeks of immersion time resulted in the total degradation of $\mathrm{NaCas}$ (Fig. 2) and in the partial degradation of SI (Fig. 1). SI demonstrated its water-resistant character, showing a rate of only $10 \%$ weight loss per week (Fig. 1). The clear reduction in the weight loss rate of the crosslinked versus the non-crosslinked protein samples, during hydrolytic degradation, is most probably due to the effect of additional bonds. Consequently, more chains need to be cleaved before the complete degradation of the specimen.

The studied proteins could also be crosslinked by TA. TA is capable of complexing or crosslinking proteins by the formation of multiple hydrogen bonds [26], rendering the proteins less water-soluble and more resistant to hydrolysis. However, because this is a partly reversible process [27] the effect of TA on the degradation profiles of SI and NaCas was not significant (Figs. 1 and 2). Only for longer periods, namely 2 weeks of immersion, TA was responsible for a decrease in the degradation rates of the proteins.

Another successful way of crosslinking proteins is by means of performing a thermal treatment on the membranes at $80^{\circ} \mathrm{C}$. This technique is especially efficient for SI proteins, leading to a reduction in the degradation rate (Fig. 1). SI membranes showed only

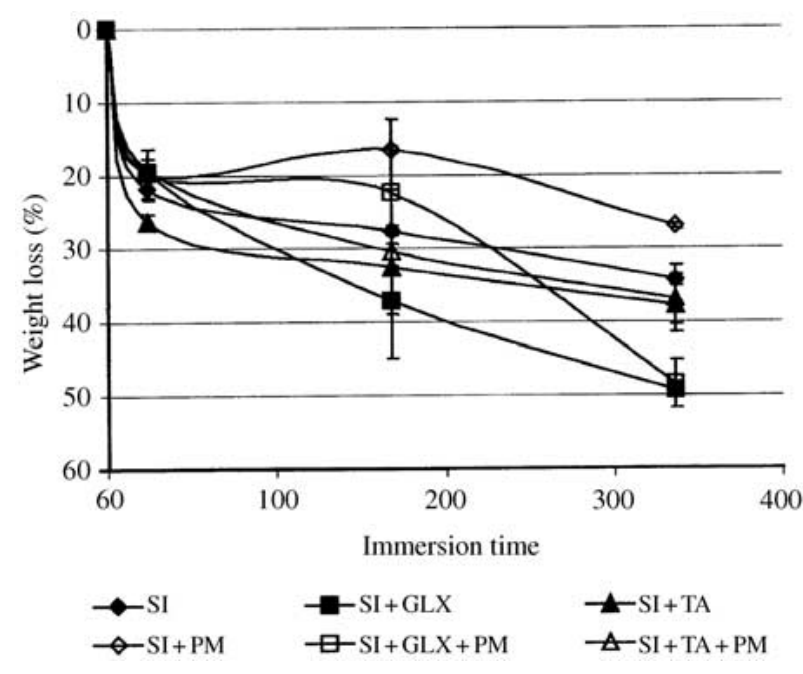

Figure 1 In vitro degradation profiles for soy protein-based membranes immersed in an isotonic saline solution at $37^{\circ} \mathrm{C}$ and $\mathrm{pH} 7.4$. SI, soy membranes; SI + PM, soy membranes physically modified (thermal treatment); SI + GLX, soy membranes crosslinked with glyoxal; SI + GLX + PM, soy membranes crosslinked with glyoxal physically modified (thermal treatment); SI + TA, soy membranes crosslinked with tannic acid; SI + TA + PM, soy membranes crosslinked with tannic acid physically modified (thermal treatment). 


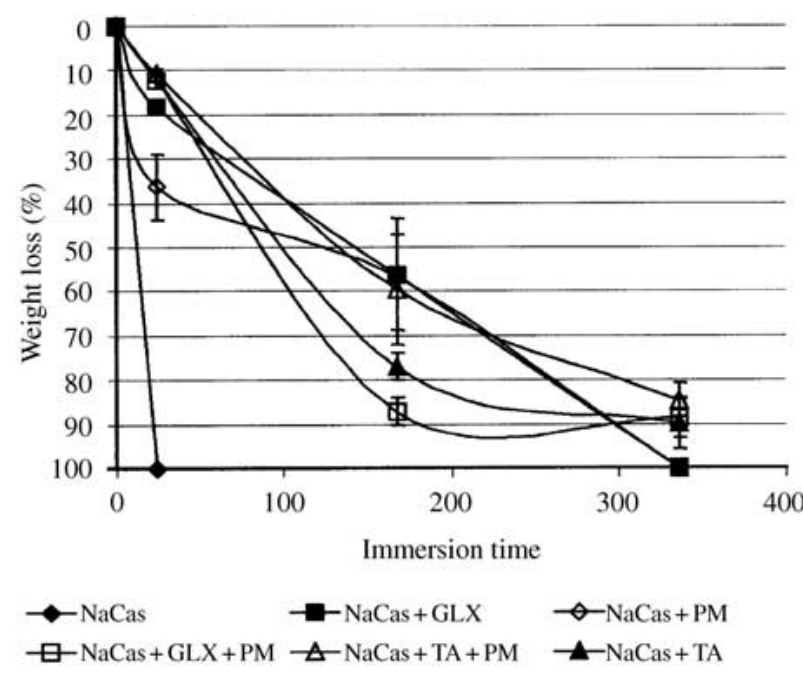

Figure 2 In vitro degradation profiles for sodium caseinate proteinbased membranes immersed in an isotonic saline solution at $37^{\circ} \mathrm{C}$ and $\mathrm{pH}$ 7.4. NaCas, sodium caseinate membranes; NaCas + PM, sodium caseinate membranes physically modified (thermal treatment); $\mathrm{NaCas}+\mathrm{GLX}$, sodium caseinate membranes crosslinked with glyoxal; $\mathrm{NaCas}+\mathrm{GLX}+\mathrm{PM}$, sodium caseinate membranes crosslinked with glyoxal physically modified (thermal treatment); NaCas $+\mathrm{TA}$, sodium caseinate membranes crosslinked with tannic acid; SI + TA + PM, soy membranes crosslinked with tannic acid physically modified (thermal treatment).

$20 \%$ weight loss during the first 7 days of immersion that was totally attributed to leaching of glycerol. During the second week of immersion SI samples lost $10 \%$ in weight. Similar effects have already been reported [28]. Heat-treated samples of $\mathrm{NaCas}$ (Fig. 2) showed fairly the same degradation profile as the NaCas-GLX crosslinked ones. The combination of crosslinking, both by glyoxal or tannic acid, with heat treatment only resulted in an additional improvement of the hydrolytic resistance for the NaCas protein (Fig. 2). It appears that NaCas is able to become more water resistant when additional hydrogen bonds (TA crosslinking and heat treatment) and covalent bonds (glyoxal crosslinking and heat treatment) are present in the internal structure of this protein. In the case of SI (Fig. 1), this combination $(\mathrm{SI}+\mathrm{GLX}+\mathrm{PM}$ and $\mathrm{SI}+\mathrm{TA}+\mathrm{PM})$ showed no profit when compared with the degradation profiles obtained with heat-treated samples $(\mathrm{SI}+\mathrm{PM})$, being the most successful way of rendering SI more water resistant.

\subsection{Water-vapor transmission rate}

Water-vapor transmission rate values (evaluated by water-vapor permeability (WVP)) of four different protein membranes (SI, SI + GLX, NaCas and $\mathrm{NaCas}+\mathrm{GLX}$ ) are shown in Fig. 3. The evaluation of WVTR was carried out due to the fact that one of the applications that are foreseen is in wound dressings and/ or skin regeneration scaffolds.

In general, NaCas membranes presented a higher WVP than the SI ones. This differences can be mostly related with the different conformations presented by both proteins: (i) SI is typically a globular protein and (ii) $\mathrm{NaCas}$ is a randomly coiled protein. However, in both cases, the crosslinked membranes resulted in a slight decrease in the WVP. This decrease can be attributed to the formation of covalent links within the hydrogel

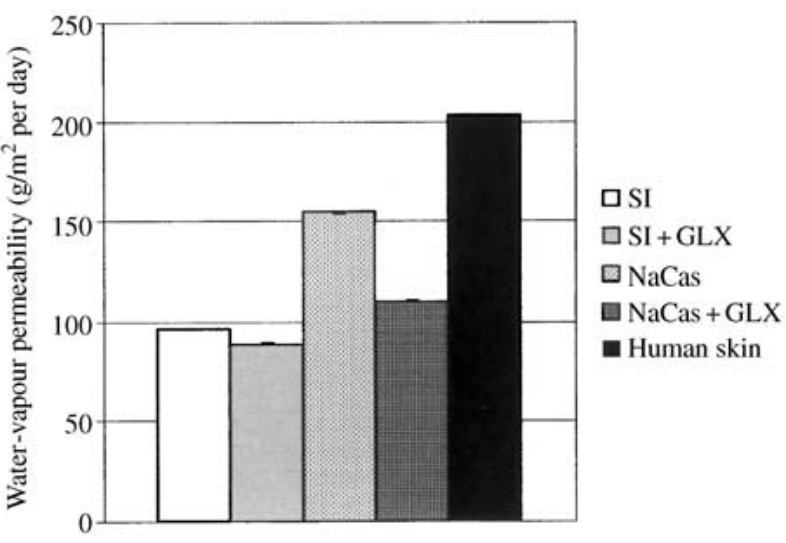

Figure 3 Water-vapor permeability for soy and sodium caseinate protein based-membranes. SI, soy membranes; SI + GLX, soy membranes crosslinked with glyoxal; NaCas, sodium caseinate membranes, NaCas + GLX, sodium caseinate membranes crosslinked with glyoxal.

during crosslinking. Similarly, it was reported that reactions of formaldehyde also decreased the WVP of protein films from corn zein [29] and gelatin films [30].

In general, the WVP of the membranes $\left(\sim 100 \mathrm{~g} / \mathrm{m}^{2}\right.$ per day for SI systems and $\sim 150 \mathrm{~g} / \mathrm{m}^{2}$ per day for NaCas systems) is smaller than that present by a normal skin (WVP $\sim 204 \mathrm{~g} / \mathrm{m}^{2}$ per day) [31]. However, the developed membranes were non-porous and the normal skin has some porosity. For the possibility of production of porous proteins membranes, the expected WVP would be higher and more similar to the WVP of human skin, especially in the case of the NaCas systems.

\subsection{Cytotoxicity studies}

\subsubsection{DMEM extraction test}

The DMEM extraction test is based on a morphological evaluation, which is validated by a scoring system that classifies them, in cytotoxic terms from 0 to 8 , being 8 the most cytotoxic score [4] as seen below.

\begin{tabular}{lll}
\hline Cytotoxicity index & Reactivity & Result of the test \\
\hline $0-1$ & None & Pass \\
$1-3$ & Slightly toxic & Pass \\
$3-5$ & Mildly toxic & Retest \\
$5-7$ & Moderately toxic & Fail \\
$7-8$ & Severely toxic & Fail \\
\hline
\end{tabular}

In addition, the samples are classified as follows: passing the test (score from 0 to 4.9 ), need for retesting (5.0) or failing the test (5.1-8). A negative score means that the material performed better than the negative control. The retest score does not mean that the sample is deleterious to the cells, but it should be retested in order to assess its final score. For further details on the method, see Gomes et al. [4]. It should be stressed out that this test functions only as an indicator of the materials behavior.

Table II displays the results for the tested samples, which were scored relatively to the positive (latex rubber extract, maximum cytotoxic effect) and negative control (DMEM culture medium, no cytotoxic effect).

The scoring system allows determining the reactivity of the materials, by classifying them as passing the test, needing retesting or failing the test. From Table II it is 
T A B L E I I Samples $\left(3 \times 1 \mathrm{~cm}^{2}\right)$ score for DMEM extraction test. The scoring is obtained by means of using an Excel scoring system that uses parameters, such as cell morphology, cell death, confluence of the monolayer and cell number based on the same parameters of the positive and negative controls, namely cells with culture medium and cells in contact with latex, which is known by its high cytotoxicity

\begin{tabular}{|c|c|c|c|}
\hline Condition & Score & Reactivity & Test \\
\hline Soy & 0.3 & None & Pass \\
\hline Soy + physical modification & 2.3 & Slight & Pass \\
\hline Soy $+15 \%$ glyoxal & -0.7 & None & Pass \\
\hline Soy $+15 \%$ glyoxal + physical mod. & 0.0 & None & Pass \\
\hline Soy + tannic acid & 4.7 & Mild & Retest \\
\hline Soy + tannic acid + physicals mod. & 5.0 & Mild & Retest \\
\hline $\mathrm{NaCas}$ & 1.0 & None/Slight & Pass \\
\hline $\mathrm{NaCas}+$ physical modification & 2.0 & Slight & Pass \\
\hline $\mathrm{NaCas}+$ glyoxal & 4.0 & Mild & Retest \\
\hline $\mathrm{NaCas}+$ tannic acid & 4.3 & Mild & Retest \\
\hline $\mathrm{NaCas}+$ tannic acid + physical mod. & 4.5 & Mild & Retest \\
\hline
\end{tabular}

possible to see that only the samples crosslinked with tannic acid display a higher score, indicating a slight cytotoxic effect over the cells. Of course, this can be eventually solved in future studies just by trying to remove extra tannic acid after the crosslinking treatment. In this study this was not done because the idea was just to compare the cytotoxicity of the systems produced in different conditions, including the use of distinct crosslinkers.

Even though it is not an acute cytotoxic effect, since the score is rated as "retest", which means that the samples should be further retested before they can be classified as toxic for cells. The higher cytotoxic value present in Table II -5.0 - is the limit after which the materials fail the test $(>5.1-8)$. In this way, although the leachables extracted from these materials exert a somewhat toxic effect, they do not present a full cytotoxic effect, which enable to say that all the samples passed the test. However, further tests to evaluate their behavior are needed, since this is just a standard morphological evaluation test.

\subsubsection{MTT test}

Biochemical tests such as MTT test are fairly accurate measurements of the behavior of the cells in direct/ indirect contact with the materials to be evaluated. MTT test is a well known and widely used biochemical test to assess cell viability, and indirectly, cell proliferation in a qualitative way [32] when related to other biochemical tests.

Figs. 4 and 5 display the results for the viability of cells in indirect contact with soy and casein-based membranes as measured by the MTT reduction test. For an easier visualization, the results for each sample are presented as percentage of control, i.e. the control (cells and culture medium) is rated as $100 \%$, and the values plotted on Figs. 4 and 5 are percentages obtained by comparison with the control. The results plotted are a representative experiment from three different experiments performed with reproducible results.

By analysis of the bar graph, it is possible to see that only soy membranes crosslinked with tannic acid display a partial cytotoxic effect over the cells. Tannic acid was used as crosslinking agent at $0.9 \%$ (wt \% relative to the protein content) and apparently some toxic leachables related with tannic acid must have leached out of the membranes, causing cell death. The same effect has been previously reported [31]. The low percentage of viability observed for membranes crosslinked with tannic acid only confirms the results previously obtained on the DMEM test.

Soy membranes (SI) and soy membranes crosslinked with glyoxal (SI + GLX) display viability percentages higher than $100 \%$, which can be related to higher proliferation rates than the control itself, which is a very good result, not typical at all for biodegradable systems. The MTT test scores only for living cells, so the fact that some samples present higher percentage of viability than the control means that cells are alive and proliferating. A possible explanation for this higher score is the possibility the extracts from the membranes may contain some amino acids that leached from the membrane due to some peptide bond breaking, and these amino acids can be uptake by the cells to enter their metabolism, thus enhancing cell growth and proliferation. For the total protein quantification, extracts were quantified for leached peptides as described in the Materials and methods section. The results showed that, in fact, some peptides leach out of the membranes as detected by the BCA reagent (data not shown), which could support for the above stated explanation. Relating these results with the ones obtained for the weight loss determination, it is readily visible that the higher the weight loss, the more

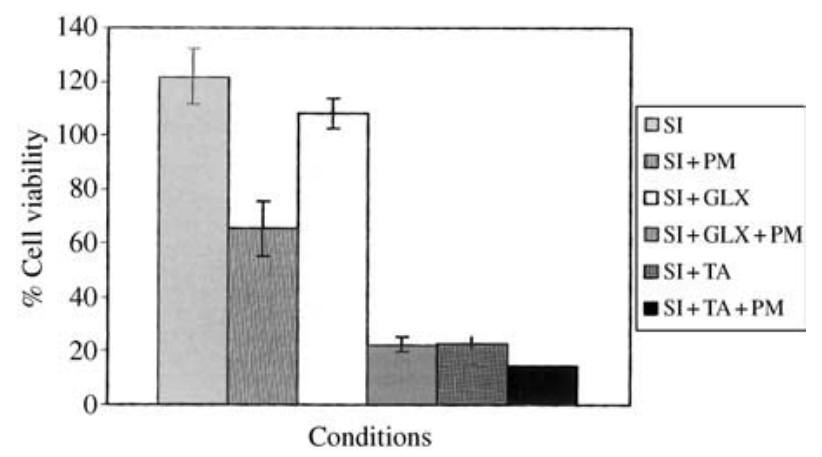

Figure 4 Percentage of cell viability determined by the MTT test for soy-based membranes $\left(3 \times 1 \mathrm{~cm}^{2}\right)$. The percentage of viable cells was determined relating the optical density of each sample with the optical density from the control, which is considered to have $100 \%$ viability. SI, soy membranes; SI + PM, soy membranes physically modified (thermal treatment); SI + GLX, soy membranes crosslinked with glyoxal; SI + GLX + PM, soy membranes crosslinked with glyoxal physically modified (thermal treatment); SI + TA, soy membranes crosslinked with tannic acid; SI + TA + PM, soy membranes crosslinked with tannic acid physically modified (thermal treatment). 


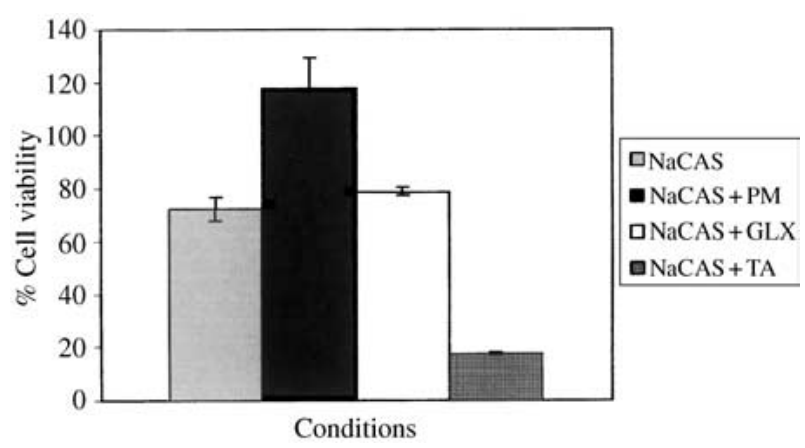

Figure 5 Percentage of cell viability determined by the MTT test for sodium caseinate membranes $\left(3 \times 1 \mathrm{~cm}^{2}\right)$. The percentage of viable cells was determined relating the optical densities of each sample with the optical density from the control, which is considered to have $100 \%$ viability. NaCAS, sodium caseinate membranes; NaCAS + PM, sodium caseinate membranes physically modified (thermal treatment); $\mathrm{NaCAS}+\mathrm{GLX}$, sodium caseinate membranes crosslinked with glyoxal; $\mathrm{NaCAS}+\mathrm{TA}$, sodium caseinate membranes crosslinked with tannic acid.

amino acids (and other leachables) will be released to the medium, rendering them more available for uptake by the cells.

An interesting result for soy membranes that underwent physical modification by means of thermal treatment is that this physical modification seems to lead to a decrease in the viability of cells.

For sodium caseinate-based membranes, Fig. 5 displays the results as percentage of the control, as for soybased membranes.

For sodium caseinate-based membranes, again tannic acid exerts a toxic effect over the cells, which is clearly seen by the percentage value (about 20\%) of the control. This result is in accordance with the results previously shown for soy membranes crosslinked with tannic acid.

As already observed for soy membranes, there is a condition - sodium caseinate subjected to physical modification - that displays a higher value than the control (around 120\%). Opposite to soy membranes, that when subjected to physical modification (heat treatment) present lower values than membranes not subjected to this treatment, in this case thermal treatment seems to enhance the effects - beneficial effects - of sodium caseinate membranes over cells. These different behaviors can eventually be related with the degradation profiles of the referred membranes. As reported in Section 3.1 of Results, the heat treatment is much more effective decreasing the degradation rates of the SI membranes than the NaCas ones. As a result, for the same time of contact with cells, the amount of amino acids leached to the solutions due to some peptide bond breaking is higher in the case of the NaCas membranes, which in accordance with the hypothesis of amino acid uptake by the cells, could explain the increase in the cell growth and proliferation values.

The other conditions present a relative $20 \%$ less viability than the control, which can be considered as a good result.

\subsubsection{Total protein quantification}

It is important to state that the test used to measure the total protein content does not reveal viable cells, since

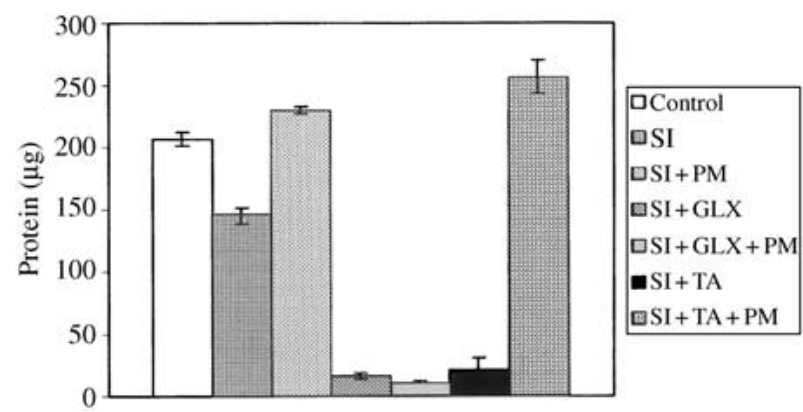

Figure 6 Protein content for soy-based membranes $\left(3 \times 1 \mathrm{~cm}^{2}\right)$. Results are plotted as $\mu \mathrm{g}$ of protein. To each sample the value of protein content of the corresponding extract was subtracted. SI, soy membranes; SI + PM, soy membranes physically modified (thermal treatment); SI + GLX, soy membranes crosslinked with glyoxal; SI + GLX + PM, soy membranes crosslinked with glyoxal physically modified (thermal treatment); SI + TA, soy membranes crosslinked with tannic acid; $\mathrm{SI}+\mathrm{TA}+\mathrm{PM}$, soy membranes crosslinked with tannic acid physically modified (thermal treatment).

this assay does not discriminate between living, dying an dead cells [33], oppositely to the MTT test, which only reveals viable cells. The total protein quantification test quantifies all the protein present in the well, which means that cells in an early phase of a programmed cell death process will be quantified, although not alive. The results, however, when interrelated with other biochemical and morphological tests, are validated and can contribute to a better understanding of the underlying phenomena.

The quantification of total protein is an accurate measurement of the proliferation ability of cells. The results for this quantification are plotted in Figs. 6 and 7. In Fig. 6, which displays the results obtained for soybased membranes, the results for soy (SI) and soy membranes physically modified (thermal treatment) $(\mathrm{SI}+\mathrm{PM})$ are similar to the control, which indicates that these conditions do not exert a inhibitory effect on cell proliferation. The difference between the two conditions can have an explanation in the fact that an increase in cell-cell contacts leads to a decrease in cell protein content [34]. For soy membranes crosslinked with glyoxal (SI + GLX), the results indicate that they

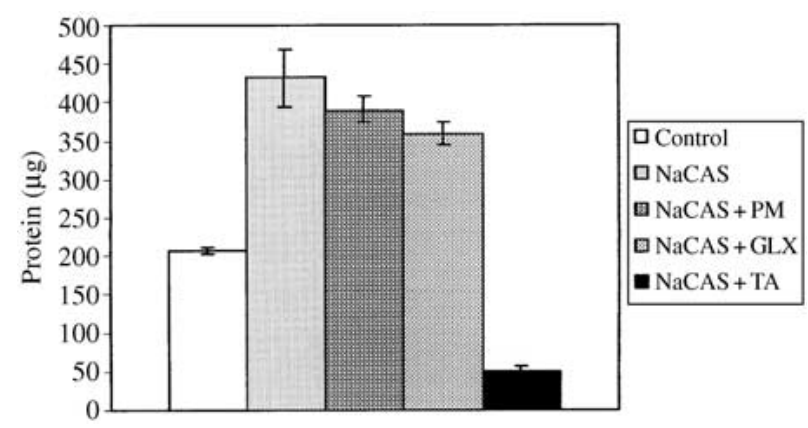

Figure 7 Protein content for sodium caseinate-based membranes $\left(3 \times 1 \mathrm{~cm}^{2}\right)$ as measured for the total protein quantification test. Results are plotted as $\mu \mathrm{g}$ of protein. To each sample the value of protein content of the corresponding extract was subtracted. NaCAS, sodium caseinate membranes; $\mathrm{NaCAS}+\mathrm{PM}$, sodium caseinate membranes physically modified (thermal treatment); NaCAS + GLX, sodium caseinate membranes crosslinked with glyoxal; NaCAS + TA, sodium caseinate membranes crosslinked with tannic acid. 


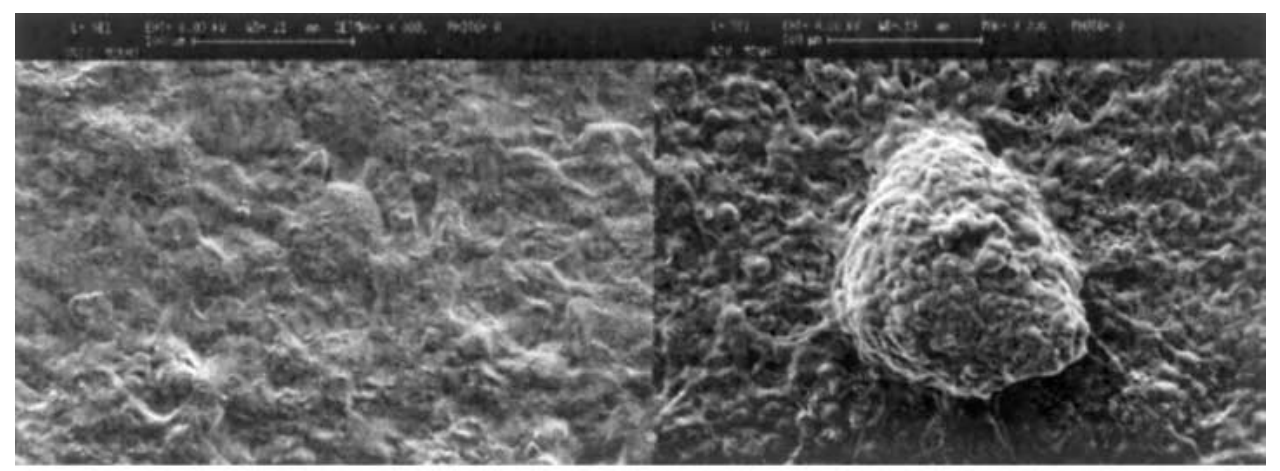

(8.1)

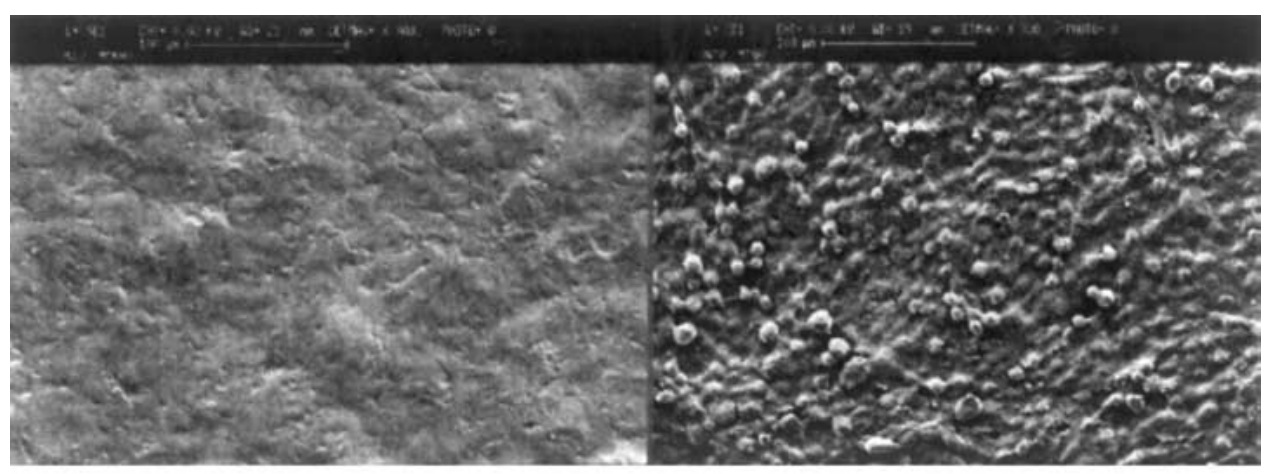

(8.2)

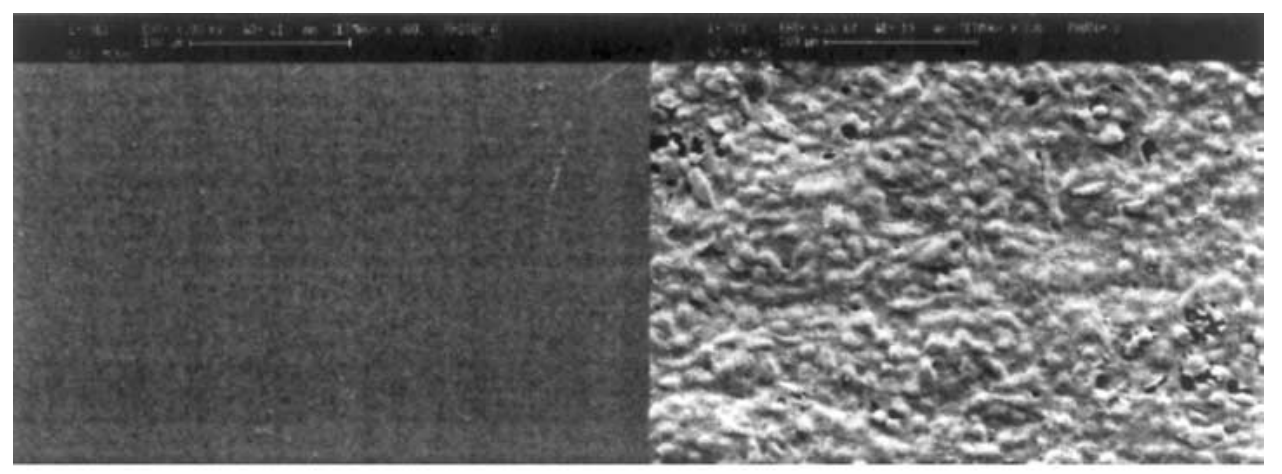

(8.3)

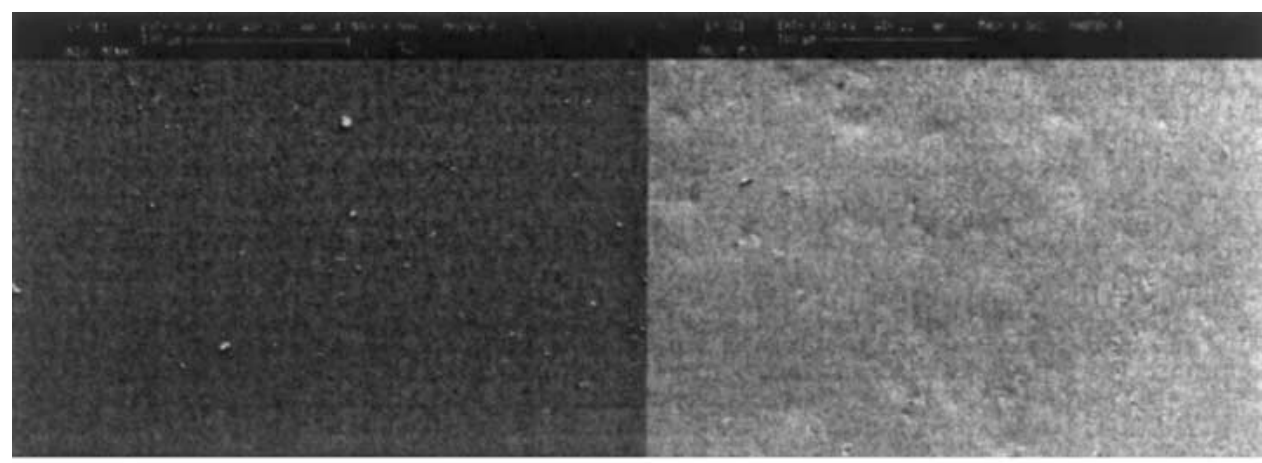

(8.4)

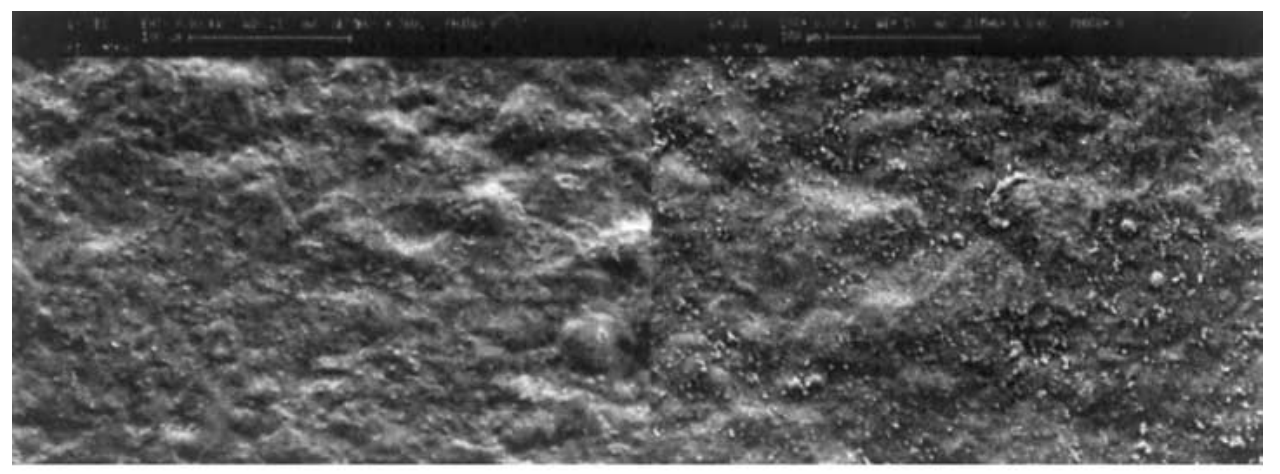

(8.5) 


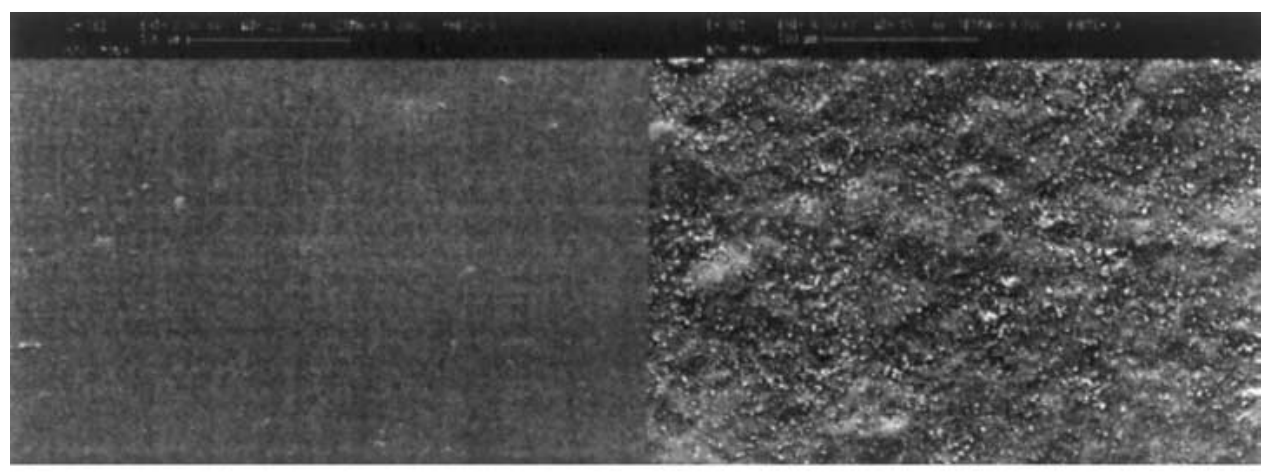

(8.6)

Figure 8 Scanning electron microscope images of the SI-based membranes $\left(1 \times 1 \mathrm{~cm}^{2}\right)$ without contact with cells (a) and after 7 days of co-culture with L929 cells (b). (8.1) SI, soy membranes. (a) day 0; (b) day 7. (8.2) SI + PM, soy membranes physically modified (thermal treatment), (a) day 0; (b) day 7. (8.3) SI + GLX, soy membranes crosslinked with glyoxal. (a) day 0; (b) day 7. (8.4) SI + GLX + PM, soy membranes crosslinked with glyoxal physically modified (thermal treatment). (a) day 0; (b) day 7. (8.5) SI + TA, soy membranes crosslinked with tannic acid. (a) day 0 ; (b) day 7. (8.6) SI + TA + PM, soy membranes crosslinked with tannic acid physically modified (thermal treatment). (a) day 0 ; (b) day 7.

seem to inhibit largely cell proliferation, although not the viability of the cells (Fig. 4, MTT test).

Soy crosslinked with tannic acid $(\mathrm{SI}+\mathrm{TA})$ results for total protein are in accordance with the results of the previous tests (DMEM and MTT). The leachables of this condition have shown to have a deleterious effect over the cells viability and as seen in Fig. 6, also over cell proliferation.

The fact that physical modification (thermal treatment) increases the crosslinking strength between protein chains, as shown by the lower weight loss seen for the soy conditions which underwent this treatment, can in fact prevent the leaching of toxic components out of the membranes, such as tannic acid, which could explain the somewhat unexpected results seen for soy membranes crosslinked with tannic acid subjected to physical treatment $(\mathrm{SI}+\mathrm{TA}+\mathrm{PM})$.

In the case of $\mathrm{NaCas}$ membranes, the results obtained show that with the exception of the sample crosslinked with tannic acid, that displays a marked inhibitory effect over cell proliferation, all other conditions present higher total protein values than the control itself. This result can be explained by the high in vitro degradation rates (weight loss) seen for caseinate membranes (Fig. 2), which could enhance the proliferation of cells by the uptake of amino acids important to the cellular metabolism.

\subsection{Adhesion and proliferation studies 3.4.1. SEM analysis}

The adhesion of the fibroblasts to the membranes was also evaluated by SEM analysis at 0 and 7 days. The preparation of the samples for SEM did not show to alter the properties or the surface of the membranes (data not shown). Figs. 8 and 9 show the morphology of soy and casein membranes, respectively, without contact with cells and after 7 days of cell culture in direct contact with the tested materials.

The results for soy membranes (SI) (Fig. 8.1) show a film of cells formed on the surface of the membrane, and the image presented (b) details a cell cluster formed on the surface of the membranes. For soy membranes subjected to thermal treatment $(\mathrm{SI}+\mathrm{PM})$, the cells appear highly adhered to the surface of the membrane, also forming a film (Fig. 8.2). The same result is observed for soy membranes crosslinked with glyoxal (SI + GLX) (Fig. 8.3), whereas for soy membranes crosslinked with glyoxal but subjected to physical modification (thermal treatment) $(\mathrm{SI}+\mathrm{GLX}+\mathrm{PM})$ no adhered cells were present (Fig. 8.4). The fact that glyoxal crosslinks the membranes between aldehyde groups of the glyoxal molecule and the free $\varepsilon$-amine groups of lysine and hydroxylysine of the polypeptide chain can account for this result. If this were the single explanation, then the SI + GLX membranes would also display a similar result to $\mathrm{SI}+\mathrm{GLX}+\mathrm{PM}$. In this way, we are forced to conclude that the thermal treatment diminishes the cell adhesion capability of the membranes, by rendering the reactive groups present at the surface of the membrane less available for cell adhesion. When tannic acid was used as crosslinking agent either condition - non-physically modified (Fig. 8.5) and physically treated (Fig. 8.6) - very few cells with rounded morphology are present on the surface. This result is in accordance with the previous results for DMEM, MTT and total protein tests, where the membranes crosslinked with tannic acid are shown to have some cytotoxic effect over cells.

For sodium caseinate membranes, the results from SEM observation are as observed in Fig. 9.

For sodium caseinate membranes, the results show that sodium caseinate membranes either untreated ( $\mathrm{NaCas}$ ) (Fig. 9.1) or subjected to physical treatment (NaCas + PM) (Fig. 9.2) have properties that allow cell adhesion and proliferation, as evidenced by the film of cells on the surface of these two conditions.

For membranes crosslinked with glyoxal $(\mathrm{NaCas}+\mathrm{GLX})$ (Fig. 9.3), proliferating cells with typical morphology are seen on the surface of the membrane. As expected, for membranes crosslinked with tannic acid (Fig. 9.4 and 9.5) a very low number of cells are adhered to the surface, as happened for soy membranes, although at 24 and $48 \mathrm{~h}$ some cells are already adhered to the surface of these membranes (data not shown). 


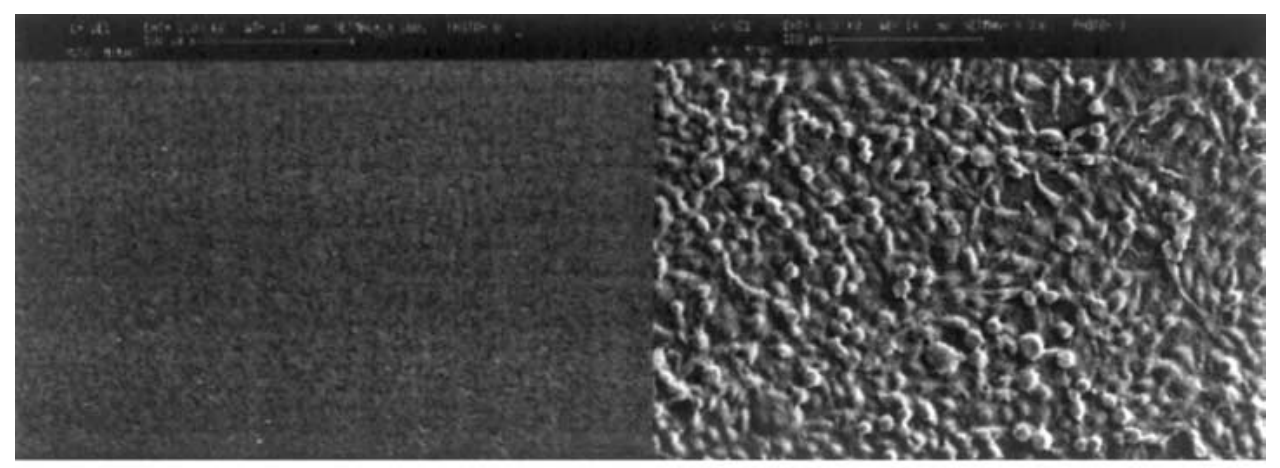

(9.1)

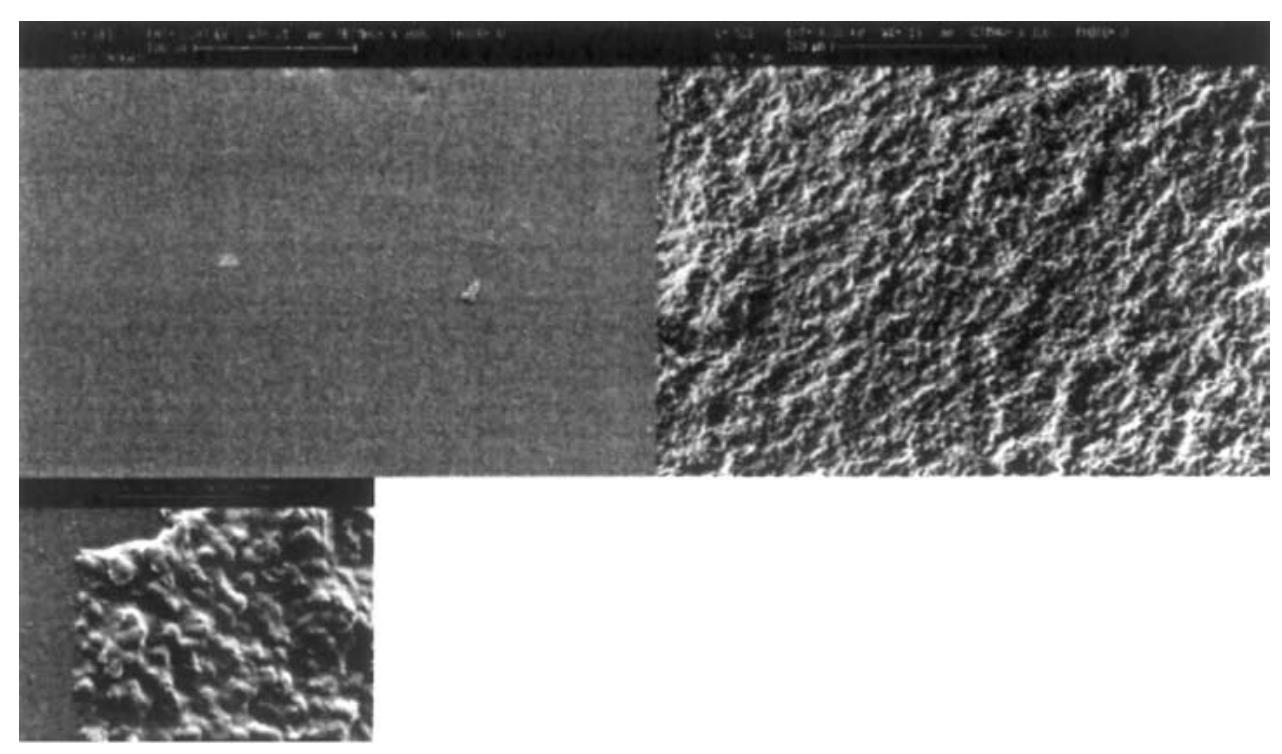

(9.2)

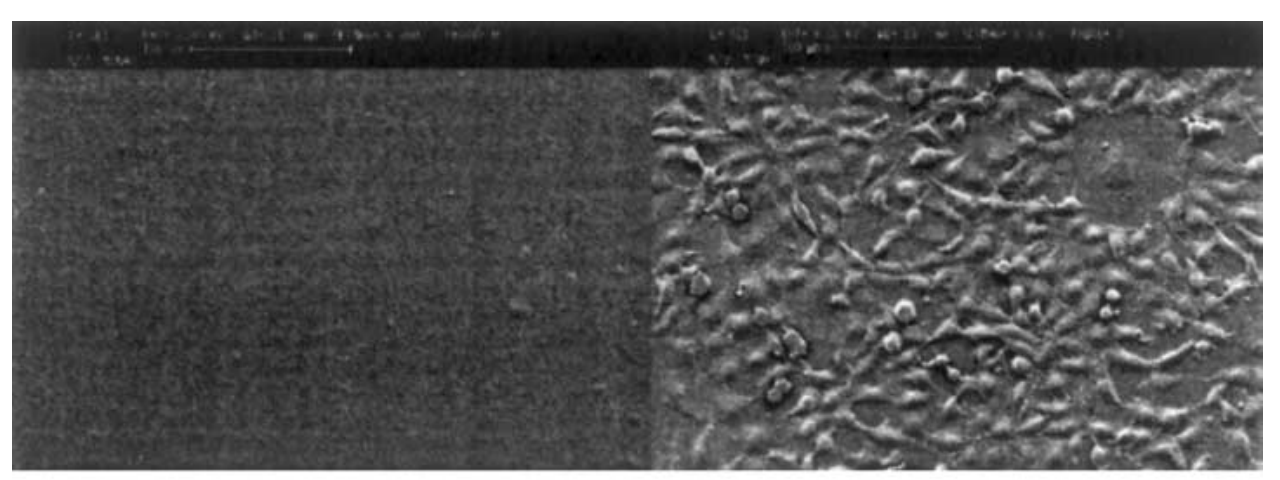

(9.3)

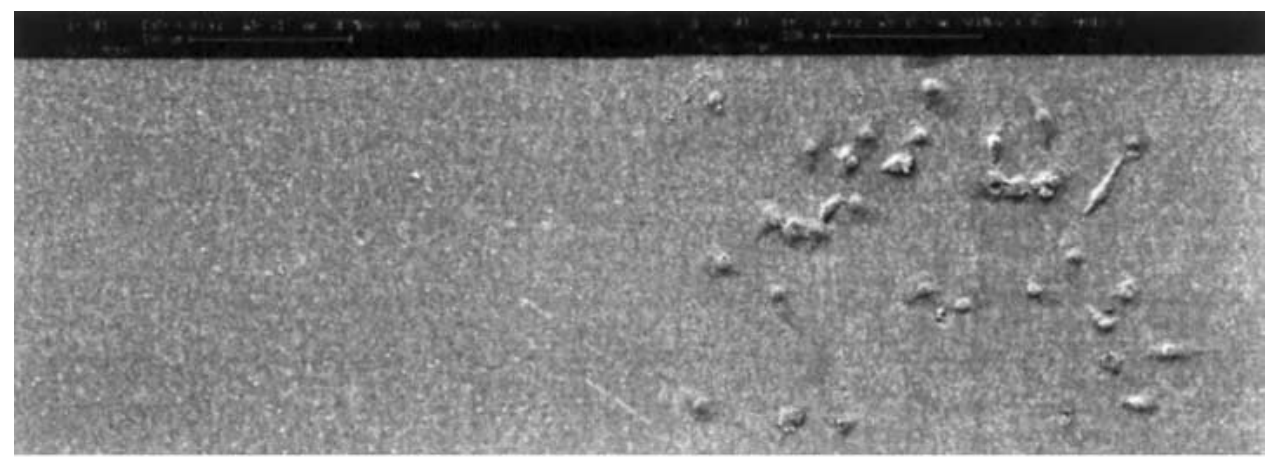

(9.4) 


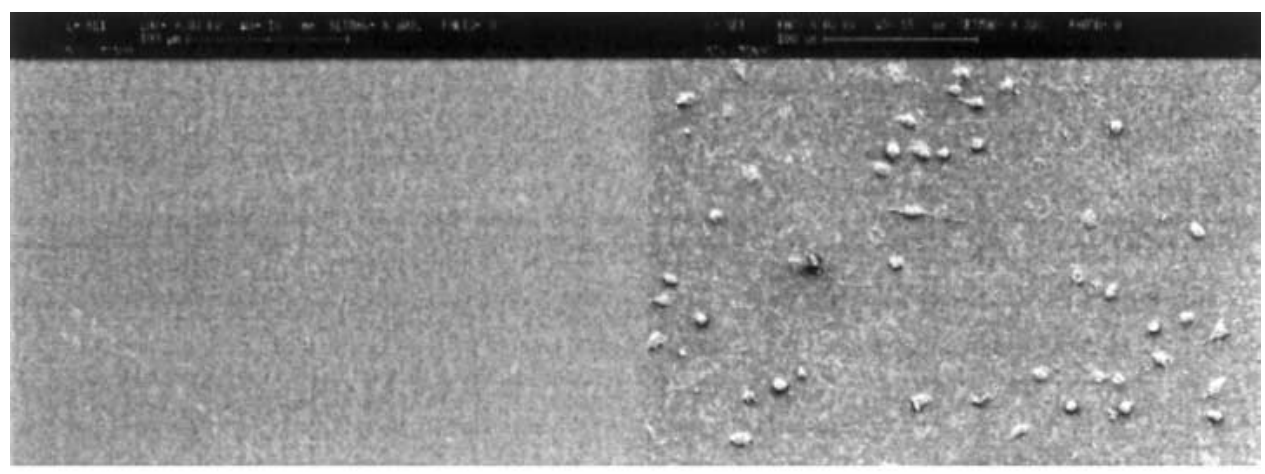

$(9.5)$

Figure 9 Scanning electron microscope images of the NaCAS-based membranes $\left(1 \times 1 \mathrm{~cm}^{2}\right)$ without contact with cells (a) and after 7 days of coculture with L929 cells (b). (9.1) NaCas, sodium caseinate membranes. (a) day 0; (b) day 7. (9.2) NaCas + PM, sodium caseinate membranes physically modified (thermal treatment). (a) day 0; (b) day 7; (c) day 7, detail. (9.3) NaCas + GLX, sodium caseinate membranes crosslinked with glyoxal. (a) day 0; (b) day 7. (9.4) NaCas + TA, sodium caseinate membranes crosslinked with tannic acid. (a) day 0; (b) day 7. (9.5) $\mathrm{NaCas}+\mathrm{TA}+\mathrm{PM}$, sodium caseinate membranes crosslinked with tannic acid physically modified (thermal treatment). (a) day 0 ; (b) day 7.

\section{Conclusions}

The aim of this study was to assess the cytotoxicity of soy and casein-based membranes by biochemical tests, and correlating the obtained results with mechanical properties of these materials, namely degradation and water uptake capability. The previous works on these materials were all performed in terms of mechanical and physical properties as well as on their potential applicability on different biomedical uses [10-12,17]. Since these materials are to be used in biomedical applications, such as drug delivery systems and skin regeneration systems, their characterization in terms of biological behavior, namely their cytotoxic profile, must be assessed.

All the tests performed, either biochemical or morphological, proved to be suitable for the evaluation of the cytocompatibility of the membranes, and the results of all the evaluation tests seem to be coherent among themselves. In vitro degradation studies show that physical modification of the membranes diminishes the weight loss of the materials, due to an increase in the crosslinking effect. This treatment causes a reduction in the leached molecules from the materials, which affect their biological performance.

$\mathrm{NaCas}$ membranes are less readily crosslinked by chemical and physical agents, which accounts for their higher weight loss values, which means that there is a higher percentage of leached materials, that can have either a deleterious or beneficial effect over cells. Tannic acid has shown to render the membranes where it was used as a crosslinking agent, slightly cytotoxic, although the heat treatment shows to reduce partly the toxic effect over cells. On the contrary, glyoxal crosslinked membranes exhibiting a clearly non-cytotoxic behavior. The behavior of the materials in contact with cells reflects clearly the results obtained for in vitro degradation tests. A following step will be the attempt of reducing the toxic effects of tannic acid by washing the membranes prior to its cell culture testing.

The studied materials shown a good behavior in the presence of the cells, seeming to be able to, in some cases, induce cell proliferation, which can be highly advantageous in biomedical applications. Also their surface properties seem to be adequate for cell adhesion and proliferation, as seen by SEM analysis.

As a final remark, it is possible to say that the materials tested in this work have a great potential for being used in biomedical applications, such as drug delivery systems and wound repair systems.

\section{Acknowledgments}

G. A. Silva is a recipient of a FCT (Fundação para a Ciência e Tecnologia) grant (SFRH/BD/4648/2001) as well as C. M. Vaz (BD/21544/99).

\section{References}

1. C. E. SCHMIDT and J. M. B AIER, Biomaterials 21 (2000) 2215.

2. C. S. PEREIRA, A. M. CUNHA, R. L. REIS, B. VÁSQUEZ and J. S AN ROMAn, J. Mater. Sci.: Mater. Med. 9 (1998) 825.

3. R. L. REIS, A. M. CUNHA and M. J. BEVIS, Appl. Med.Polym. 2 (1998) 49.

4. M. E. GOMES, R. L. REIS, A. M. CUNHA, C. A. BLITTERWIJK and J. D. BRUIJN, Biomaterials 22 (2001) 1911.

5. P. B. MALAFAYA, C. ElviRA, A. GALlARDO, J. SAN ROMAN and R. L. REIS, J. Biomater. Sci. Polym. Edn. 12 (2001) 1227.

6. M. E. GOMES, A. S. RIBEIRO, P. B. MALAFAYA, R. L. REIS and A. M. CUNHA, Biomaterials 22 (2001) 883.

7. S. C. MENDES, R. L. REIS, Y. P. BOVELL, A. M. CUNHA, C. A. BLITTERWIJK and J. D. BRUIJN, ibid. 22 (2001) 2057.

8. A. P. MARQUES, R. L. REIS and J. A. HUNT, ibid. 23 (2002) 1471.

9. A. J. SAlgado, M. E. Gomes, A. ChOU, O. P. COUtinho, R. L. REIS and D. W. HUTCHMAKER, Mater. Sci. Eng.: C. 20 (2002) 27.

10. C. M. VAZ, J. F. MANO, M. FOSSEN, R. F. VAN TUIL, L. A. DE GRAAF, R. L. REIS and A. M. CUNHA, J. Macromol. Sci. Phys. B 41 (2002) 33.

11. C. M. VAZ, M. FOSSEN, R. F. VAN TUIL, L. A. DE GRAAF, R. L. REIS and A. M. CUNHA, J. Biomed. Mater. Res. 65A (2003) 60-70.

12. C. M. VAZ, L. A. DE GRAAF, R. L. REIS and A. M. CUNHA, in "Polymer Based Systems on Tissue Engineering, Replacement and Regeneration', edited by R. L. Reis and D. Cohn (Kluwer Academic Publishers, Dordrecht, 2002).

13. D. G. DALGLEISH, in "Food Proteins" (American Oil Chemists Society, Champagne, 1989) p. 155.

14. J. E. Kinsella, CRC Crit. Rev. Food. Sci. 21 (1984) 197. 
15. M. YUFERA, E. PASCUAL and C. FERNANEZ-DIAZ, Aquacult. 177 (1999) 249.

16. P. F. H. HARMSEN, M. H. VINGERhoEDS, L. B. J. M. BERENDSEN, R. M. HARRISON and J. M. VEREIJKEN, IFSCC Magazine 4 (2001) 34.

17. C. M. VAZ, L. A. DE GRAAF, R. L. REIS and A. M. CUNHA, J. Biomater. Sci.: Polym. Ed. (2002) (submitted).

18. L. CALANDrlli, B. IMMirzi, M. MALINCONICO, G. ORSELLO, M. G. VOLPE, F. D. RAGIONE and V. ZAPPIA, J. Biomed. Mater. Res. 59 (2002) 611.

19. Iso/document 10993. Biological compatibility of medical devices-Part 5. Test for cytotoxicity: in vitro methods, December 1992.

20. Annual Book of ASTM Standards, American Society for Testing and Materials, West Conshohocken, 4.06 (1980) 629.

21. J. ZELTINGER, J. K. SHERWOOD, D. A. GRAHAM, R. MUELleR and L. G. GRIFFITh, Tissue Eng. 7 (2001) 557.

22. T. F. Slater, B. SAWYer and U. STRAUli, Biochim. Biophys. Acta 77 (1963) 383.

23. T. MOS MANN, J. Immunol. Methods 65 (1983) 55.

24. P. K. S MITH, Anal. Biochem. 150 (1985) 76.

25. H. SING H, Trends Food Sci. Technol. 2 (1991) 196.

26. F. H. HEIJMEN, Biomaterials 18 (1997) 749.
27. R. N. RAngavajhyala, V. M. Ghorpade and M. A. HANn A, J. Agric. Food Chem. 45 (1997) 4204.

28. Y. Ali, V. M. GHORPADE and M. A. HANNA, Ind. Crops Prod. 6 (1997) 177.

29. A. JUliU S, Food Wrapping Membrane, U.S. Patent No. 3329509 (1967).

30. F.-L. MI, S.-S. SHYU, Y.-B. WU, S.-T. LEE, J.-Y. SHYONG and R.-N. HUANG, Biomaterials 22 (2001) 163.

31. S. M. AL-SHAFI, Saudi Med. J. 23 (2002) 221.

32. H. PRIGENT, P. PELlEN-MUSSi, G. CATHELineau and M. Bonnaure-Mallet, J. Biomed. Mater. Res. 39 (1998) 200.

33. S. Bouillaguet, J. C. Wataha, M. Virgillito, L. GONZALEZ, D. R. RAKICH and J.-M. MEYER, Dental Mater. 16 (2000) 213.

34. A. V. CARVALHAL, A. S. COROADINHA, P. M. ALVES, J. L. MOREIRA, H. HAUSER and M. T. CARRONDO, Enz. Mic. Tech. 30 (2002) 95.

Received 4 December 2002

and accepted 17 June 2003 